\title{
ADHD 坚童の前頭前野活動に及ぼすアトモキセチンの効果
}

\author{
一近赤外分光法（NIRS）を用いた検討一 \\ ○池上将永・荒木章子 (非会員) ・ 高橋雅治 \\ (旭川医科大学医学部) \\ キーワード : 注意欠如・多動性障害, アトモキセチン, 前頭前野
}

\begin{abstract}
Prefrontal hemodynamic activity in ADHD children treated with atomoxetine: A near-infrared spectroscopy study Masanaga IKEGAMI, Akiko ARAKI and Masaharu TAKAHASHI
\end{abstract}

(Faculty of Medicine, Asahikawa Medical Univ.)

Key Words: attention-deficit/hyperactivity disorder, atomoxetine, prefrontal cortex

\section{目 的}

注意欠如・多動性障害（attention-deficit/hyperactivity disorder; ADHD）は，不注意·多動性·衝動性を中核症状とする発達障 害であり，持続的注意や反応抑制を中心とした前頭葉機能と の関連が推測されている。ADHD の治療には主に中枢刺激薬 であるメチルフェニデート (methylphenidate; MPH) が用いら れ，行動評価に加えて EEG や fMRI を用いた脳機能計測によ り投薬の効果が検証されてきた。また最近では近赤外分光法 （near-infrared spectroscopy; NIRS）を用いた投薬効果の評価も 報告されている（池上ら, 2007; Monden et al., 2011）。

一方, 非中枢刺激薬であるアトモキセチン (atomoxetine; ATX）の前頭前野活動に及ぼす効果については, 現在のとこ ろ報告は少数である。ATX は MPH と比べて有意な行動症状 の改善が認められるまでに時間を要するため (Dickson et al., 2011), 行動評価に加えて脳機能計測による評価が投薬効果の 判定に寄与すると考えられる。

そこで本研究では, NIRS を用いて ADHD 児童の前頭前野 活動に及ぼすATXの効果について検討した。行動課題には, 持続的注意と反応抑制を要する課題である連続遂行課題

（continuous performance task；CPT） を用い，投薬治療前後に おける課題遂行中の前頭前野の血流動態反応, 行動評価尺度

(ADHD-RS) および CPT 遂行成績の変化を検証した。

$$
\text { 方 法 }
$$

実験参加者 旭川医科大学小児科外来通院中で, DSM-IV-TR に拠って診断された ADHD 览童 13 名 (男児 7 名, 女览 6 名, 平 均年齢 9.6 歳)を対象として行った。実施に先立ち, 児童と保護者 に検査の趣旨を説明し承諾を得た。ATXによる治療開始前(治療 前条件) および治療開始後 6 ケ月以上経過した時点 (治療後条件) の2回の検査を行った。ATXの平均維持量は $1.6 \mathrm{mg} / \mathrm{kg}$ であった。 課題 警告刺激の直後に現れる標的刺激に対して反応を求める CPT-AXを用いた。刺激には 0 から 9 までの数字を用い, ディスプ レイ中央にランダムな順で呈示した。刺激呈示時間は $200 \mathrm{~ms}$, 刺 激開始間間隔は $1000 \mathrm{~ms}$ であった。被験児は警告刺激である“1” の直後に標的刺激“9”が出現した場合, 出来る限り素早くキーを 押して反応することが求められた。

手続き 実験は 300 試行から構成され, 60 試行ずつの 5 ブロック に分割されて実施された。1ブロックに要する時間は 60 秒であつ た。各ブロックの間には 30 秒間の安静期間を設け, NIRS 計測に おけるベースラインとした。課題遂行成績は全 300 試行を通して 分析し, ヒット率, ヒット反応時間, および警告刺激直後の非標的 刺激に対する誤反応 (false alarm; FA)の生起率を算出した。

NIRS 計測 光卜ポグラフィ装置（ETG-100, 日立メディコ）を 用いて課題遂行中の酸素化へモグロビン (oxy-Hb) と脱酸素 化へモグロビン（deoxy-Hb）の濃度変化を計測した。計測プ ローブは左右の前頭部を覆うように設置した。5 ブロック分 の時系列データを加算平均したのち, 課題期間の開始直前 6 秒間と課題期間終了 12 秒後からの 6 秒間のデータを用いて直
線回帰によりベースラインを推定し, 課題遂行時の $\mathrm{Hb}$ 濃度 変化をチャンネルごとに算出した。

\section{結 果}

行動指標 ADHD-RS 得点は治療後条件で有意に低下した。一 方, CPT におけるヒット率, 反応時間, FA 生起率に関して, 治療前後で有意な差は認められなかった（Table 1)。

NIRS データ 課題期間における oxy-Hb の濃度変化について, 治療前条件と治療後条件を比較した結果, 治療前条件では安 静時ベースラインと比べて oxy-Hb 量の有意な変化は認めら れなかった。対照的に, 治療後条件では左右の前頭前野背外 側部 $(\mathrm{CH} 9, \mathrm{CH} 21)$ で oxy-Hb 量の有意な増加が認められた。 また, 治療後条件における左背外側部・腹外側部 $(\mathrm{CH} 8-9, \mathrm{CH} 12)$ および右背外側部 (CH21-22) の oxy-Hb 量は, 治療前条件よ りも有意に大きかった（Fig. 1)。

Table 1 Behavioral performance and ADHD-RS-IV-J scores.

\begin{tabular}{ccccc}
\hline & \multicolumn{3}{c}{ Continuous performance task } & \\
\cline { 2 - 4 } Condition & Hit (\%) & RT for hit (ms) & False alarm (\%) & $\begin{array}{c}\text { ADHD-RS-IV-J } \\
\text { total score }\end{array}$ \\
\hline pre-ATX & $91.79 \pm 10.24$ & $390.93 \pm 78.17$ & $8.21 \pm 16.59$ & $35.15 \pm 6.78^{* *}$ \\
post-ATX & $92.82 \pm 10.70$ & $378.24 \pm 109.22$ & $6.67 \pm 10.18$ & $19.77 \pm 5.75$ \\
\hline
\end{tabular}

Values are given as means \pm standard deviation. ${ }^{* *} p<0.01$.
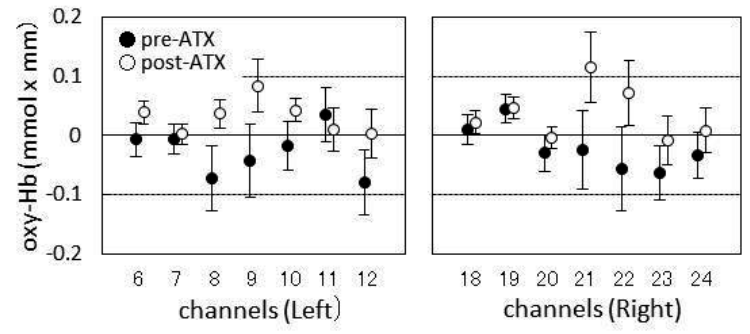

Fig. 1 課題期間における oxy-Hb 量の平均値 考 察

先行研究と一致して, 6 ケ月以上の ATX 内服によって ADHD-RS 得点は有意に改善された。一方, 本研究では CPT を短時間のブロックに分割して実施したため, 遂行が比較的 容易であり, 治療前後における CPT 遂行成績に有意な差は認 められなかった。NIRS 計測の結果, ATX 治療後では課題遂 行に伴う前頭前野背外側部の有意な活動が認められ, 治療に よる前頭前野機能の改善が示唆された。ATXによる行動症状 の改善は漸進的であるため（Dickson et al., 2011）, NIRS によ る前頭前野機能の測定を合わせて行うことは ATX の投薬効 果を評価する際に有用であると考えられる。 